\title{
Biochemical and Neurobiological Study of Moroccan Autists
}

\author{
Hakim Harchaoui ${ }^{1}$, Fatima-Zahra Azzaoui ${ }^{1}$, Ahmed Ahami ${ }^{1}$, Samira Boulbaroud ${ }^{2}$, Mohamed El Hioui ${ }^{1}$ \\ ${ }^{1}$ Equip of Clinic and Cognitive Neurosciences and Health, Laboratory of Biology and Health, Department of Biology, Faculty of \\ Science, IBN TOFAIL University, Kenitra, Morocco; ${ }^{2}$ Equip of Neuroendocrine Physiology, Faculty of Science, IBN TOFAIL Uni- \\ versity, Kenitra, Morocco. \\ Email: hakim.harchaoui@gmail.com
}

Received August $7^{\text {th }}, 2013$; revised September $5^{\text {th }}, 2013$; accepted October $3^{\text {rd }}, 2013$

Copyright (C) 2013 Hakim Harchaoui et al. This is an open access article distributed under the Creative Commons Attribution License, which permits unrestricted use, distribution, and reproduction in any medium, provided the original work is properly cited.

\begin{abstract}
Autism spectrum disorder (ASD) is a range of complex neurodevelopment disorders, characterized by social impairments, communication difficulties, and restricted, repetitive, and stereotyped patterns of behavior. Its diagnosis is very difficult and consists of only clinical criteria. The aim of this study is to confirm autism disorder, among three children ( 2 girls and 1 boy), recruited in a social association of children in a precarious situation, located in Rabat, Morocco, and to evaluate some biological and neurobiological parameters among these children. The confirmation of autistic status is realized using Questionnaire (E2) and the evaluation of biological parameters (organic acids, urinary peptides, toxic metals and essential elements) is done in urine and hair of these children. Obtained children's scores of E2 Questionnaire, is found in the favor of autism. Moreover, abnormal levels of urinary organic acids, urinary peptides, toxic and essential metals are observed.
\end{abstract}

Keywords: Autism; Neurobiology; Organic Acids; Toxic Metals; Essential Elements

\section{Introduction}

Autism, as defined by "The Diagnostic and Statistical Manual of Mental Disorders", 4th edition (DSM IV) (2000), is a disorder of neural development characterized by impaired social interaction and verbal and non-verbal communication, and by restricted, repetitive or stereotyped behavior. The diagnostic criteria require that symptoms become apparent before a child is three years old.

In Morocco, very few studies are realized about autism [1] which cannot provide the prevalence in the Kingdom. However, the prevalence of this neurodevelopmental disorder is increasing; in the USA, from 1998 to 2007, the number of 6- to 21-year-old children receiving services for an ASD (autism spectrum disorders) in public special education programs increased from 54,064 to 258,305 [2]. In the recent CDC report, it is found that the overall estimated prevalence of ASD is one in 88 children during [3].

The etiology of autism is still discussed and some studies report that autism affects approximately three times as many males as females. Taken together with studies looking at families and twins, this suggests that autism has a genetic component. It is likely that a number of genes are involved. However, the exact mechanism by which genes are implicated in autism is unclear [4]. Other findings suggest that some neuroanatomical impairments in brain areas and/or brain chemistry changing could be involved in this neuropathology $[5,6]$.

Moreover, some studies have reported many nutriational deficiencies in autism [7], and accumulations of organic acids in urine can indicate metabolic dysfunction, nutrient insufficiencies, or even microbial overgrowth [8]. The urinary organic acids test measures selected metabolites which serve as important diagnostic indicators of abnormal metabolism in the case of autistic children. The measurement of organic acids in urine evaluates four critical areas of metabolism: gastrointestinal function, cellular energy and mitochondrial metabolism, neurotransmitter metabolism, and amino acid/organic acid balance as influenced by vitamin/mineral cofactors [9]. In the urine of many autistic children, abnormal metabolites such as opioid peptides and [10] abnormal levels of different organic acids $[11,12]$ were observed. Some researches 
about this pathology implicated insufficient enzymatic activity and increased gastrointestinal permeability, and the absorption of toxic byproducts of incompletely digested proteins from dairy (casein) and cereals (gluten), [13,14].

Furthermore, environmental pollution could be a possible factor contributing to this disease [15]; many metals could be implicated in autism since they typically disrupt enzyme functions and cell signaling processes, generate oxygen free radicals (ROS) and elicit autoimmune reactions [16]. Metals involved in physiopathological processes include essential elements such as zinc (Zn), copper $(\mathrm{Cu})$, iron $(\mathrm{Fe})$, calcium $(\mathrm{Ca})$, manganese $(\mathrm{Mn})$, nickel (Ni) and silicon $(\mathrm{Si})$, or toxic metals such as cadmium $(\mathrm{Cd})$, cobalt $(\mathrm{Co})$, aluminium $(\mathrm{Al})$, lead $(\mathrm{Pb})$, mercury $(\mathrm{Hg})$ and arsenic (As) $[17,18]$. The laboratory analysis of different biological matrices (urine, blood, hair) is very useful in identifying this deficiency or toxicity and allow for health professionals establishing possible strategies of treatment. The aim of this study, in one hand is to contribute to this field, and still virgin in Morocco, and in the other hand, to confirm autistic diagnosis of studying children and to measure some biological and neurobiological parameters in hair and urine of these children.

\section{Patients and Methods}

\subsection{Ethical Clearance and Informed Consent}

This study was approved by the Internal Ethics Committee of Faculty of Science, Kenitra, Morocco and by the GDRI of Neurosciences France-Morocco Ethics Committee. The recruitment of patients is based on the following criteria:

- Written consent of the children's parents,

- Children physically healthy and not previously undergone chelation therapy, free of any medication, without any casein-free and gluten-free diet and any medical issues.

\subsection{Patients}

Three children ( 2 girls and 1 boy) are involved in the present study. They are aged between 15 to 18 years old. The children are diagnosed for autism and they are inserted into an associative structure in Rabat, Morocco, that cares for children suffering from neurobehavioral impairments.

Patient (A): Aya, female child aged 4 years is diagnosed with autism. Aya is the second of three sisters and she is physically normal. She had frequent infections breathing during the first months of life. She learned to walk alone between 24 and 36 months. Between $2^{\text {cd }}$ and $4^{\text {th }}$ year, she had an irresistible urge to eat something. At the age of 3 or 4 years, she is "going into a shell"; she became so distant and lost in thought. Moreover, she was indifferent to any affection and seems to be happier when we do not take care of her. Before 5 years, she was able to speak but not to answer. Her abnormal behavior has been discovered between 7 and 12 months.

Patient (B): Salwa, female child of 18 years is diagnosed with autism. Salwa is the younger child of her family, she is physically normal. Salwa had a difficulty of sucking and diarrhea. She learned to walk alone between 8 and 12 months. Between $2^{\text {cd }}$ and $4^{\text {th }}$ year, she suffers from PICA syndrome. At the age of 3 or 4 years, she is "going into a shell"; she became so distant and lost in thought. Moreover, she was indifferent to any affecttion and seems to be happier when we do not take care of her. Before 5 years, she was able to speak but not to answer. Her abnormal behavior has been discovered between 13 and 24 months.

Patient (C): Ismail 17 years old, male diagnosed with autism. Ismail is the only child in his family, he is physically normal with an excellent health. He learned to walk alone between 8 and 12 months. Between 2 and 4 years, he sucks often metallic objects. A child at the age of 3 or 4 years was "locked in his shell" or so distant and lost in thought. He is indifferent to any brand of affection and seems being happier when you do not take care of him. Before 5 years, he was able to speak but not to answer. The abnormal behavior of the child has been discovered between 2 and 3 years.

\subsection{Methods}

An E2 Questionnaire, including 79 amnestic items for the diagnosis of autism, completed by parents, is used. It covers the period from birth to age of 5 years. All items are summed to obtain a total score. If an item is applicable to the assessed individual, it is noted $(+1)$, if not, it is noted $(-1)$. The total score is the difference between the presence of autism $(+)$ and its absence $(-)$. A total score of " 20 " is in the favor of autism [19].

The urine and hair samples were collected from the patients for the following biological tests: Tests of urinary organic acids including neurotransmitters, fatty acids, amino acids, bacterium and fungal metabolites. Test of urinary peptides including casamorphin and glutenmorphin. Test of toxic metals ( $\mathrm{Ur}, \mathrm{Al}, \mathrm{As}, \mathrm{Pb}, \mathrm{Hg}, \mathrm{Ag}$ ) and essential elements $(\mathrm{Ca}, \mathrm{Mg}, \mathrm{Na}, \mathrm{k}, \mathrm{Cu}, \mathrm{Cr}, \mathrm{Mo}, \mathrm{Se}$, $\mathrm{Be}, \mathrm{Ru}, \mathrm{Zn}, \mathrm{Va}, \mathrm{Li})$ in the hair samples. All the analysis is realized by Great plain laboratory, Inc (USA).

The urinary organic acids and urinary peptides results are expressed as ratios to the urinary creatinin concentration in $\mathrm{mmol} / \mathrm{mmolcreatinine}$. Certified hair standards and in-house standards were used as part of the laboratory quality control and for the validation of results. Results are expressed as micrograms per gram, equivalent to parts per million. 


\section{Results}

\subsection{Evaluation of Children's Autistic Status by E2 Questionnaire}

The scores of patients A, B and C, in the E2 Questionnaire are respectively 36,28 and 26 (Table 1 ).

\subsection{Organic Acids and Peptides in Children's Urine}

The patient $\mathrm{A}$ has a deficit in pyroglutamic acid (17.69 $\mathrm{mmol} / \mathrm{mmolcreatinine})$ and in ascorbic acid (1.09 $\mathrm{mmol} /$ mmolcreatinine). However, she has an excess of vanylmandelic acid $(7.80 \mathrm{mmol} / \mathrm{mmolcreatinine})$, 3-oxoglutaric acid (0.67 mmol/mmolcreatinine), arabinose (147.57 $\mathrm{mmol} / \mathrm{mmolcreatinine})$, Cytramalyc acid (2.69 $\mathrm{mmol} /$ mmolcreatinine), 4-hydroxyphenylacetic acid (150.73 $\mathrm{mmol} / \mathrm{mmolcreatinine})$ and in Oxalic acid (150.73 $\mathrm{mmol} /$ mmolcreatinine), (Table 2).

The patient $\mathrm{B}$ has a deficit in pyroglutamic acid (15.48 $\mathrm{mmol} / \mathrm{mmolcreatinine)}$ and an absence of ascorbic acid (0.00 $\mathrm{mmol} / \mathrm{mmolcreatinine})$. However, she has an excess of Suberic acid (3.89 $\mathrm{mmol} / \mathrm{mmolcreatinine}), 3$ oxoglutaric acid (0.84 $\mathrm{mmol} / \mathrm{mmolcreatinine})$, arabinose (123.86 $\mathrm{mmol} / \mathrm{mmolcreatinine})$, Citric acid (855.71 $\mathrm{mmol} / \mathrm{mmolcreatinine})$ and in 2-Oxo-glutaric acid (3.08 $\mathrm{mmol} / \mathrm{mmolcreatinine),} \mathrm{(Table} \mathrm{2).}$

The patient $C$ has a deficit in pyroglutamic acid (19.37 $\mathrm{mmol} / \mathrm{mmolcreatinine}$ ) and an absence of ascorbic acid (0.00 $\mathrm{mmol} / \mathrm{mmolcreatinine})$. However, he has an excess in Methylmalonic acid (13.55 $\mathrm{mmol} / \mathrm{mmolcreatinine})$, arabinose (696.55 $\mathrm{mmol} / \mathrm{mmolcreatinine),} \mathrm{4-hydroxy-}$ phenylacetic acid (54.07 $\mathrm{mmol} / \mathrm{mmolcreatinine})$ and in 2-Oxo-glutaric acid (144.57 $\mathrm{mmol} / \mathrm{mmolcreatinine})$, (Table 2).

Moreover, an abnormal level in both Casomorphin $1.28(\mathrm{P} / \mathrm{C}$ ratio) and Gliadorphin $1.09(\mathrm{P} / \mathrm{C}$ ratio) is registered among patient $\mathrm{A}$, and in only Gliadorphin 0.78 ( $\mathrm{P} / \mathrm{C}$ ratio) in patient $\mathrm{B}$ (Table 3 ).

\subsection{Levels of Toxic Metals and Oligoelements in Autistic Children's Hair}

Levels of some Toxics exceed widely the reference range; Patient A has a high level of $\mathrm{Al}(6.6 \mu \mathrm{g} / \mathrm{g})$ and low exceeding in As $(0.082 \mu \mathrm{g} / \mathrm{g})$ and $\mathrm{Pb}$ levels $(1.1 \mu \mathrm{g} / \mathrm{g})$. Patient $\mathrm{B}$ has the same level of $\mathrm{Al}$ than patient $\mathrm{A}$, but he has a higher level of $\mathrm{Hg}(1.2 \mu \mathrm{g} / \mathrm{g})$ and $\mathrm{Ag}(0.2 \mu \mathrm{g} / \mathrm{g})$. Patient $\mathrm{C}$ has a very high level of $\mathrm{Al}(14 \mu \mathrm{g} / \mathrm{g})$ and $\mathrm{Ur}(0.12$ $\mu \mathrm{g} / \mathrm{g}$ ), (Table 4).

Levels of some oligoelements are less or more than the normal range; Patient A suffer from a deficiency in $\mathrm{Ca}$ (349 $\mu \mathrm{g} / \mathrm{g}), \mathrm{Mg}(18 \mu \mathrm{g} / \mathrm{g}), \mathrm{Cu}(7.6 \mu \mathrm{g} / \mathrm{g})$. However, the levels of $\mathrm{Na}(410 \mu \mathrm{g} / \mathrm{g}), \mathrm{K}(1200 \mu \mathrm{g} / \mathrm{g}), \mathrm{Cr}(0.53 \mu \mathrm{g} / \mathrm{g}), \mathrm{B}$ $(8.5 \mu \mathrm{g} / \mathrm{g})$ and $\mathrm{Ru}(0.80 \mu \mathrm{g} / \mathrm{g})$ exceed the normal ranges.

Patient B has no deficiency in these oligoelements, but an excess in $\mathrm{Na}(290 \mu \mathrm{g} / \mathrm{g}), \mathrm{K}(270 \mu \mathrm{g} / \mathrm{g}), \mathrm{B}(2.8 \mu \mathrm{g} / \mathrm{g})$, $\mathrm{Ru}(0.16 \mu \mathrm{g} / \mathrm{g}), \mathrm{Zn}(240 \mu \mathrm{g} / \mathrm{g})$, Va $(0.19 \mu \mathrm{g} / \mathrm{g})$ and $\mathrm{Li}$ $(0.19 \mu \mathrm{g} / \mathrm{g})$.

Table 1. The children's scores in questionnaire E2.

\begin{tabular}{ccccc}
\hline & Patient A & Patient B & Patient C & Normal Score \\
\hline Total & 36 & 28 & 26 & $<20$
\end{tabular}

Table 2. Levels of organic acids in the urine of autistic children ( $\mathrm{mmol} / \mathrm{mmolcreatinine})$.

\begin{tabular}{|c|c|c|c|c|c|}
\hline \multicolumn{2}{|c|}{ Organic acids } & \multirow{2}{*}{$\begin{array}{c}\text { Patient A } \\
17.69\end{array}$} & \multirow{2}{*}{$\frac{\text { Patient B }}{15.48}$} & \multirow{2}{*}{$\begin{array}{c}\text { Patient C } \\
19.37\end{array}$} & \multirow{2}{*}{$\frac{\text { Reference range }}{20-115}$} \\
\hline Amino acid metabolites & Pyroglutamic acid & & & & \\
\hline Fatty acid metabolites & Subericacid & 1.81 & 3.89 & 1.88 & $0-2$ \\
\hline \multirow{2}{*}{ Various organic acids } & Methylmalonic acid & 1.81 & 1.64 & 13.55 & $0-5$ \\
\hline & Ascorbic acid & 1.09 & 0.00 & 0.00 & $10-200$ \\
\hline \multirow{2}{*}{ Neurotransmitters } & Homovanilic acid & 2.62 & 2.14 & 4.98 & $0-10$ \\
\hline & Vanylmandelic acid & 7.80 & 3,69 & 5.82 & $1-6.6$ \\
\hline \multirow{3}{*}{ Yeast/fungal } & 3-oxoglutaric acid & 0.67 & 0.84 & 0 & $0-0.5$ \\
\hline & Arabinose & 147.57 & 123.86 & 696.55 & $0-47$ \\
\hline & Cytramalic acid & 2.69 & 1.53 & 1.53 & $0-2$ \\
\hline Bacterium & 4-hydroxyphenylacetic acid & 150.73 & 4.89 & 54.07 & $0-50$ \\
\hline \multirow{2}{*}{ Krebs Cycle } & Citric acid & - & 855.71 & 446.77 & $180-560$ \\
\hline & 2-Oxo-glutaric acid & 42.12 & 3.08 & 3.08 & $15-200$ \\
\hline Various & Oxalicacid & 150.73 & 30.27 & 144.57 & $0-100$ \\
\hline
\end{tabular}


Table 3. Levels of urinary peptides in autistic children (Relative $(\mathbf{P} / \mathrm{C})^{*}$ Ratio report.

\begin{tabular}{ccccc}
\hline Peptides & Patient A & Patient B & Patient C & $\begin{array}{c}\text { Relative } \\
\text { Normal } \\
\text { Ratio }\end{array}$ \\
\hline Casomorphin (Milk) & 1.28 & 0.54 & 0.28 & $<0.56$ \\
Gliadorphin (Wheat) & 1.09 & 0.78 & 0.09 & $<0.58$ \\
\hline
\end{tabular}

${ }^{*} \mathrm{P} / \mathrm{C}$ ratio: peptides $(\mathrm{ng} / \mathrm{ml}) /$ Creatinin $(\mathrm{mg} / \mathrm{dl})$.

Table 4. Concentrations of toxic metals $(\mu \mathrm{g} / \mathrm{g})$.

\begin{tabular}{ccccc}
\hline Toxic metals & Patient A & Patient B & Patient C & Reference range \\
\hline Uranium (Ur) & 0.003 & 0.052 & 0.12 & $<0.06$ \\
Aluminum (Al) & 6.6 & 6.6 & 14 & $<0.8$ \\
Arsenic (As) & 0.082 & 0.043 & 0.03 & $<0.060$ \\
Lead (Pb) & 1.1 & 0.92 & 0.89 & $<1$ \\
Mercury (Hg) & 0.13 & 1.2 & 0.18 & $<0.40$ \\
Silver (Ag) & 0.04 & 0.20 & 0.06 & $<0.16$ \\
\hline
\end{tabular}

Patient $\mathrm{C}$ is deficient in $\mathrm{Mo}(0.024 \mu \mathrm{g} / \mathrm{g})$ and $\mathrm{Se}(0.89$ $\mu \mathrm{g} / \mathrm{g})$ only and he has an excess in $\mathrm{Ca}(2260 \mu \mathrm{g} / \mathrm{g}), \mathrm{Mg}$ $(250 \mu \mathrm{g} / \mathrm{g}), \mathrm{K}(51 \mu \mathrm{g} / \mathrm{g}), \mathrm{Cu}(40 \mu \mathrm{g} / \mathrm{g}), \mathrm{Zn}(300 \mu \mathrm{g} / \mathrm{g}), \mathrm{Va}$ $(0.13 \mu \mathrm{g} / \mathrm{g}), \mathrm{Li}(0.56 \mu \mathrm{g} / \mathrm{g})$, (Table 5).

\section{Discussion}

The pathogenesis of autism remains elusive, autism is considered a multifactorial disorder that is influenced by genetic, environmental and immunological factors. Rimland questionnaire (E2 Questionnaire) is used in this study to confirm the autistic status of patients. The obtained scores in this questionnaire show that the patients are autistic. [20] had used this questionnaire, also, to distinguish the autistic from non-autistic studied children.

The analysis of organic acids in human body fluids such as plasma, urine and cerebro-spinal fluid is very important. This is necessary for the diagnosis of inborn errors of metabolism of amino and organic acids and for individual patient's diagnosis of nutrient requirements [8]. Organic acids are important metabolites in major metabolic pathways such as the Krebs cycle or the pentose phosphate pathway. The accumulation of organic acids in biological fluids, especially in urine, can also provide useful information for an early diagnosis of metabolic disorders and neurological diseases $[8,11,12,21]$.

The current finding shows a high to very high levels in some organic acids (suberic, methylmalonic, 3-oxoglutaric, Cytramalic, 4-hydroxyphenylacetic, Oxalic acids and arabinose) among at least one of the children. [22] found a marked increase in the analogs of Krebs cycle metabolites in the urine of two brothers with autistic features. These metabolites included citramalic, tartaric (3-
Table 5. Concentrations of essential elements ( $\mu \mathrm{g} / \mathrm{g})$.

\begin{tabular}{ccccc}
\hline $\begin{array}{c}\text { Essential } \\
\text { elements }\end{array}$ & Patient A & Patient B & Patient C & $\begin{array}{c}\text { Reference } \\
\text { range }\end{array}$ \\
\hline Calcium (Ca) & 349 & 919 & 2260 & $350-1000$ \\
Magnesium (Mg) & 18 & 120 & 250 & $35-120$ \\
Sodium (Na) & 410 & 290 & 70 & $12-90$ \\
Potassium (K) & 1200 & 270 & 51 & $7-36$ \\
Copper (Cu) & 7.6 & 15 & 40 & $12-35$ \\
Chrome (Cr) & 0.53 & 0.35 & 0.35 & $0.20-0.40$ \\
Molybdenum (Mo) & 0.043 & 0.033 & 0.024 & $0.029-0.06$ \\
Selenium (Se) & 1.0 & 1.0 & 0.89 & $0.95-1.7$ \\
Bore (B) & 8.5 & 2.8 & 1.4 & $0.30-1.5$ \\
Rubidium (Ru) & 0.80 & 0.16 & 0.038 & $0.01-0.06$ \\
Zinc (Zn) & 130 & 240 & 300 & $130-220$ \\
Vanadium (Va) & 0.053 & 0.19 & 0.13 & $0.02-0.07$ \\
Lithium (Li) & 0.030 & 0.19 & 0.56 & $0.01-0.02$ \\
\hline
\end{tabular}

OH-malic), and 3-oxoglutaric acids and compounds tentatively identified as a citric acid analog and partially identified as a phenylcarboxylic acid and in arabinose. Moreover, [23] detected abnormal amino acid metabolism, increased oxidative stress, and altered gut microbiome in autistic children.

Quantification of urinary homovanillic acid (HVA) and vanillylmandelic acid (VMA) can be a very important tool in the study of disorders of dopamine and serotonin metabolism among autistic children. This study demonstrates a higher level of VMA among one patient. $[11,12]$ found, recently, that The levels of HVA and VMA were higher in the urine of autistic children compared to control ones.

Furthermore, the current results show a high level of casein and gluten in patients. Several research suggests gluten-free and casein-free diets for autistic children [2426]. A recent investigations, prove the efficiency of freecasein and free-gluten diet on improvement of autistic children's health status $[27,28]$.

Besides of metabolic factors' involvement in autism syndrome, impairments in metallic trace element could have an effect also; the increase in autism incidence in the last two decades has led scientists to propose the environmental pollution as a possible factor contributing to this disease [15]. Heavy metals are environmental contaminants whose levels have been dramatically increased by the modern industrialization. Many metals could be implicated in autism since they typically disrupt enzyme functions and cell signaling processes, generate oxygen free radicals (ROS) and elicit autoimmune reactions [16]. 
A number of studies have implicated exposure to various metals in the development of autism [17,18,29] but, to date, the mechanisms by which metals exposure may cause autism have been difficult to ascertain.

All these findings are consistent with our results that find very high levels of $\mathrm{Ur}, \mathrm{Al}, \mathrm{As}, \mathrm{Pb}, \mathrm{Hg}$ and $\mathrm{Ag}$ are registered in at least one of the patients.

In the present study, impairment in the level of the essential element is observed; high levels of $\mathrm{Na}, \mathrm{K}, \mathrm{Cr}, \mathrm{B}$, $\mathrm{Ru}, \mathrm{Zn}, \mathrm{Va}, \mathrm{Li}$ and low level of Mo and Se are found in at least of two patients. However, concerning $\mathrm{Ca}$ and $\mathrm{Cu}$, the results show high levels in some patients and low among others. Previous studies found higher levels of $\mathrm{Zn}$ in both hair and teeth [18] of autistic subjects. Others [30] found a significant elevation in the concentration of $\mathrm{Cu}$, $\mathrm{Pb}$, and $\mathrm{Hg}$ and significant decrease in the concentration of $\mathrm{Mg}$ and Se in the hair and nail samples of autistic subjects. These variations could be well correlated with degree of autism severity.

\section{Conclusions}

The studied children are autistic and suffer from impairments in organic acids, oligoelements and high levels of toxic metals.

Rimland questionnaire and biological study, using analysis of biological matrix, can be effective for confirming autistic status of patients and detecting abnormal metabolic and nutritional conditions in autistic children. In future investigations, these analyses could help to establish a medical protocol for treatment or at least improvement of health status of these children.

\section{REFERENCES}

[1] D. Saloua, L. R. Desviat, P. Belén, L. Fátima, U. Magdalena and C. Layachi, "Mutation Analysis of Phenylketonuria Patients from Morocco: High Prevalence of Mutation G352fsdelG and Detection of a Novel Mutation p.K85X," Clinical Biochemistry, Vol. 43, No. 1-2, 2010, pp. $76-81$.

[2] Centers for Disease Control and Prevention (CDC), "Prevalence of Autism Spectrum Disorders-Autism and Developmental Disabilities Monitoring Network, United States, 2006," MMWR Surveillance Summary, Vol. 58, No. SS10, 2009, pp. 1-20.

[3] Morbidity and Mortality Weekly Report (MMWR), "Prevalence of Autism Spectrum Disorders-Autism and Developmental Disabilities Monitoring Network, 14 Sites, United States, 2008," Surveillance Summaries, Vol. 61, No. SS03, 2012, pp. 1-19.

http://www.cdc.gov/mmwr/preview/mmwrhtml/ss6103a1. htm

[4] MRC, "Review of Autism Research: Epidemiology and Causes," Medical Research Council, 2001, p. 94.

[5] E. J. Carter, D. L. Williams, N. J. Minshew and J. F. Leh- man, "Is He Being Bad? Social and Language Brain Networks during Social Judgment in Children with Autism," PLoS One, Vol. 7, No. 10, 2012, Article ID: e47241. http://dx.doi.org/10.1371/journal.pone.0047241

[6] M. J. Kane, M. Angoa-Peréz, D. I. Briggs, C. E. Sykes, D. M. Francescutti, D. R. Rosenberg and D. M. Kuhn, "Mice Genetically Depleted of Brain Serotonin Display Social Impairments, Communication Deficits and Repetitive Behaviors: Possible Relevance to Autism," PLoS One, Vol. 7, No. 11, 2012, Article ID: e48975. http://dx.doi.org/10.1371/journal.pone.0048975

[7] L. T. Curtis and K. Patel, "Nutritional and Environmental Approaches to Preventing and Treating Autism and Attention Deficit Hyperactivity Disorder (ADHD): A Review," The Journal of Alternative and Complementary Medicine, Vol. 14, No. 1, 2008, pp. 79-85. http://dx.doi.org/10.1089/acm.2007.0610

[8] A. Kumps, P. Duez and Y. Mardens, "Metabolic, Nutritional, Iatrogenic, and Artifactual Sources of Urinary Organic Acids: A Comprehensive Table," Clinical Chemistry, Vol. 48, No. 5, 2002, pp. 708-717.

[9] C. K. Burdette, "How to Assess Patient Biochemical and Nutritional Individuality through Organic and Testing Townsend Letter for Doctors and Patients," New York, 2006.

[10] P. Shattock and P. Whiteley, "Biochemical Aspects in Autism Spectrum Disorders: Updating the Opioid-Excess Theory and Presenting New Opportunities for Biomedical Intervention," Expert Opinion on Therapeutic Targets, Vol. 6, No. 2, 2002, pp. 175-183. http://dx.doi.org/10.1517/14728222.6.2.175

[11] J. Kałużna-Czaplińska, M. Michalska and J. Rynkowski, "Determination of Tryptophan in Urine of Autistic and Healthy Children by Gas Chromatography/Mass Spectrometry," Medical Science Monitor, Vol. 16, No. 10, 2010, pp. 488-492.

[12] J. Kałużna-Czaplińska, E. Socha and J. Rynkowski, “Determination of Homovanillic Acid and Vanilylmandelic Acid in Urine of Autistic Children by Gas Chromatography/Mass Spectrometry," Medical Science Monitor, Vol. 16, No. 9, 2010, pp. 445-450.

[13] P. Whiteley, J. Rodgers, D. Savery and P. Shattock, “A Gluten-Free Diet as an Intervention for Autism and Associated Spectrum Disorders: Preliminary Findings," $\mathrm{Au}$ tism, Vol. 3, No. 1, 1999, pp. 45-66. http://dx.doi.org/10.1177/1362361399003001005

[14] K. Patel and L. Curtis, "A Comprehensive Approach to Treating Autism and Attention-Deficit Hyperactivity Disorder: A Pre-Pilot Study," The Journal of Alternative and Complementary Medicine, Vol. 13, No. 10, 2007, pp. 1091-1097. http://dx.doi.org/10.1089/acm.2007.0611

[15] E. Fombonne, "The Epidemiology of Autism: A Review," Psychological Medicine, Vol. 29, No. 4, 1999, pp. 769-786. http://dx.doi.org/10.1017/S0033291799008508

[16] T. O. Kleine, "How to Diagnose Humanbrain Damage and Inflammation," Brain Research Bulletin, Vol. 61, No. 3, 2003, pp. 227-228. http://dx.doi.org/10.1016/S0361-9230(03)00084-4

[17] A. Fido and S. Al-Saad, "Toxic Trace Elements in the 
Hair of Children with Autism," Autism, Vol. 9, No. 3, 2005, pp. 290-298.

[18] J. B. Adams, J. Romdalvik, V. M. Ramanujam and M. S. Legator, "Mercury, Lead, and Zinc in Baby Teeth of Children with Autism versus Controls," Journal of Toxicology and Environmental Health A, Vol. 70, No. 12, 2007, pp. 1046-1051. http://dx.doi.org/10.1080/15287390601172080

[19] B. Rimland, "The Differentiation of Childhood Psychoses: An Analysis of Checklists for 2218 Psychotic Children," Journal of Autism and Childhood Schizophrenia, Vol. 1, No. 2, 1971, pp. 161-174. http://dx.doi.org/10.1007/BF01537955

[20] I. Leddet, C. Larmande, C. Barthelemy, F. Chalons, D. Sauvage and G. Lelord, "Comparison of Clinical Diagnoses and Rimland E2 Scores in Severely Disturbed Children," Journal of Autism and Developmental Disorders, Vol. 16, No. 2, 1986, pp. 215-225. http://dx.doi.org/10.1007/BF01531731

[21] S. A. Rogers, "Using Organicacids to Diagnose and Manage Recalcitrant Patients," Alternative Therapies in Health and Medicine, Vol. 12, No. 4, 2006, pp. 44-51.

[22] W. Shaw, E. Kassen and E. Chaves, "Increased Urinary Excretion of Analogs of Krebs Cycle Metabolites and Arabinose in Two Brothers with Autistic Features," Clinical Chemistry, Vol. 41, No. 8, 1995, pp. 1094-1104.

[23] X. Ming, T. P. Stein, V. Barnes, N. Rhodes and L. Guo, "Metabolic Perturbance in Autism Spectrum Disorders: A Metabolomics Study," Journal of Proteome Research, Vol. 11, No. 12, 2012, pp. 5856-5862.

[24] B. Rimland and M. Baker, "Brief Report: Alternative Approaches to Development of Effective Treatments for Autism," Journal of Autism and Developmental Disorders, Vol. 26, No. 2, 1996, pp. 237-241.
http://dx.doi.org/10.1007/BF02172019

[25] J. H. Elder, M. Shankar, J. Shuster, D. Theriaque, S. Burns and L Sherrill, "The Gluten-Free, Casein-Free Diet in Autism: Results of a Preliminary Double Blind Clinical Trial," Journal of Autism and Developmental Disorders, Vol. 36, No. 3, 2006, pp. 413-420.

http://dx.doi.org/10.1007/s10803-006-0079-0

[26] C. Evans, H. R. Dunstan, T. Rothkirch, T. K. Roberts, K. L. Reichelt, R. Cosford, G. Deed, L. B. Ellis and D. L. Sparkes, "Altered Amino Acid Excretion in Children with Autism," Nutritional Neuroscience, Vol. 11, No. 1, 2008, pp. 9-17. http://dx.doi.org/10.1179/147683008X301360

[27] C. M. Pennesi and L. C. Klein, "Effectiveness of the Gluten-Free, Casein-Free Diet for Children Diagnosed with Autism Spectrum Disorder: Based on Parental Report," Nutritional Neuroscience, Vol. 15, No. 2, 2012, pp. 8591.

[28] C. Harris and B. Card, "A Pilot Study to Evaluate Nutritional Influences on Gastrointestinal Symptoms and Behavior Patterns in Children with Autism Spectrum Disorder," Complementary Therapies in Medicine, Vol. 20, No. 6, 2012, pp. 437-440. http://dx.doi.org/10.1016/j.ctim.2012.08.004

[29] J. K. Kern, D. A. Geier, T. Audhya, P. G. King, L. K. Sykes and M. R. Geier, "Evidence of Parallels between Mercury Intoxication and the Brain Pathology in Autism," Acta Neurobiologiae Experimentalis, Vol. 72, 2012, pp. 113-153.

[30] M. D. Lakshmi Priya and A. Geetha, "Level of Trace Elements (Copper, Zinc, Magnesium and Selenium) and Toxic Elements (Lead and Mercury) in the Hair and Nail of Children with Autism," Biological Trace Element Research, Vol. 142, No. 2, 2012, pp. 148-158. http://dx.doi.org/10.1007/s12011-010-8766-2 